\title{
Effects of oestradiol-17 $\beta$ and progesterone on the number of plasma cells in uteri of ovariectomized mice
}

\author{
M. B. Parr and E. L. Parr \\ Southern Illinois University, School of Medicine, Department of Anatomy, Carbondale, IL 62901, \\ U.S.A.
}

\begin{abstract}
Summary. Immunoglobulins $A$ and $G$ were localized by immunoperoxidase labelling in uteri of ovariectomized mice treated with oestradiol-17 $\beta$ and progesterone. The administration of oestradiol or progesterone alone to ovariectomized mice for 3 days increased the number of $\operatorname{IgA}$ plasma cells from about 1 to 14 per histological section. When the two hormones were administered simultaneously for 3 days the number of plasma cells per section was equal to or greater than with either hormone alone. Treatment with oestradiol followed by progesterone in a sequence that prepares the uterus for implantation resulted in about $31 \mathrm{IgA}$ plasma cells per section. Counts of IgG plasma cells showed similar trends but the numbers were smaller. The results indicate that progesterone increases rather than decreases the number of plasma cells in the mouse uterus. This is consistent with observations on intact mice during oestrus and pregnancy and suggests that the marked increase in endometrial plasma cells at the time of implantation in mice is a response to progesterone acting on an oestrogenprimed uterus.
\end{abstract}

\section{Introduction}

There is now substantial evidence that a local secretory immune system occurs in the female genital tract, particularly the uterus. Secretory immunoglobulin $\mathrm{A}(\mathrm{IgA})$ is present in uterine luminal fluids and probably originates, at least in part, from dimeric IgA secreted by plasma cells located in the endometrium (see Parr \& Parr, 1985a, for references). Moreover, the local immune system in the genital tract appears to be regulated by ovarian steroid hormones. In particular, the administration of oestradiol-17 $\beta$ to ovariectomized rats (Wira, Hyde, Sandoe, Sullivan \& Spencer, 1980) and mice (Canning \& Billington, 1983) caused increases in the number of endometrial plasma cells. These results are consistent with observations on intact mice, in which the number of endometrial plasma cells containing immunoglobulins $\mathrm{A}$ or $\mathrm{G}$ was greater in pro-oestrus than in dioestrus (Rachman, Casimiri, Psychoyos \& Bernard, 1983; Canning \& Billington, 1983).

The role of progesterone in regulating the number of plasma cells in the uterus is less clear. The administration of progesterone to ovariectomized rats caused little or no increase in the number of plasma cells (Wira et al., 1980), and in mice caused an increase to less than half the number observed after oestrogen treatment (Canning \& Billington, 1983). When ovariectomized rats and mice were treated with a mixture of oestradiol and progesterone, the number of uterine plasma cells was the same as or less than that observed after progesterone alone, suggesting that progesterone blocked the stimulatory effect of oestradiol (Wira et al., 1980). On the other hand, the number of uterine plasma cells in intact mice on Days 4 and 5 or pregnancy, when mainly progesterone is present (McCormack \& Greenwald, 1974), increased (Bernard, Rachman \& Bennett, 1981) or more than doubled (Parr \& Parr, 1985a) in comparison to the number present at oestrus and Day 1 of pregnancy when mainly oestrogen is present. Furthermore, there are large numbers of plasma cells of both isotypes present in the mouse endometrium from Day 11 of pregnancy to term, a period 
when both oestradiol and progesterone are present (Parr \& Parr, 1985b). Rachman, Casimiri \& Bernard (1984) have suggested that oestradiol-17 $\beta$ alone may not account for the regulation of immunoglobulins and plasma cells in the uterus during pregnancy. In an attempt to clarify the role of progesterone in the regulation of endometrial plasma cells during pregnancy, we have further studied the influence of oestradiol and progesterone on the number of plasma cells in the uterine horns of ovariectomized mice.

\section{Materials and Methods}

Animals. Outbred albino mice of the ICR strain (Harlan-Sprague-Dawley, Indianapolis, IN) were used in this study. The mice were bilaterally ovariectomized by cauterizing the ovarian artery proximal and distal to the ovary and removing a small piece of uterus, all of the oviduct, and all of the ovary with its associated fat. After allowing 3-4 weeks for recovery, vaginal smears were taken for at least 1 week, and they were uniformly similar to smears from normal mice in dioestrus. The mice were then treated with ovarian hormones (s.c.) in a variety of combinations (see Table 1), while control mice received the vehicle (peanut oil) alone. At the time of autopsy the uteri of all control animals showed regression typical of ovariectomized animals.

Tissue preparation. At 4-7 h after the last hormone injection, the mice were anaesthetized with tribromoethanol and the reproductive tracts were fixed by vascular perfusion through the thoracic aorta. Initially, the blood vessels were cleared with a solution containing $0.9 \%(\mathrm{w} / \mathrm{v}) \mathrm{NaCl}, 0.02 \%$ heparin, and $0.01 \%$ papaverine. The perfusion was continued with $4 \%$ paraformaldehyde in 0.05 M-phosphate buffer, $\mathrm{pH} 7.4\left(4^{\circ} \mathrm{C}\right)$. The uterine horns were then removed from the mice, cut into fragments, and fixed by immersion in the same fixative for $24 \mathrm{~h}$ at $4^{\circ} \mathrm{C}$. The reproductive tracts of some animals were fixed only by immersion. The fixed tissues were washed overnight in $0 \cdot 10 \mathrm{M}$-phosphate buffer, $\mathrm{pH} 7 \cdot 4\left(4^{\circ} \mathrm{C}\right)$, dehydrated in ethanols, and embedded in polyethylene glycol 1000 (PEG) as described by Mazurkiewcz \& Nakane (1972). Uterine tissues were sectioned uniformly at $6 \mu \mathrm{m}$, floated on $5 \%$ glycerol for $1 \mathrm{~h}$ to remove the PEG, and mounted on polylysinecoated slides (Wolosewick \& DeMey, 1982).

Immunolabelling. Two experiments were performed (Table 1). Uterine tissues from Exp. I were labelled to detect immunoglobulins $A$ or $\mathrm{G}$ using the following indirect immunoperoxidase technique: sections were incubated in $2 \%$ normal sheep serum, $1 / 50$ th dilution of heavy chainspecific rabbit anti-mouse IgA or IgG (Litton Bionetics, Inc., Charleston, SC), 1/100th dilution of peroxidase-conjugated sheep $F\left(a^{1}\right)_{2}$ fragment anti-rabbit IgG (Cappel Laboratories, Inc., Malvern, PA), and a substrate solution of diaminobenzidine $(50 \mathrm{mg} / 100 \mathrm{ml}$ Tris- $\mathrm{HCl}, \mathrm{pH} 7 \cdot 6)$ and $0.01 \%$ hydrogen peroxide. The sections were incubated at room temperature with intermediate washings in phosphate-buffered saline (PBS). The sections were not counterstained. Tissues from Exp. II were labelled by the avidin-biotin method as recommended by Vector Laboratories (Burlingame, CA). This method has been reported to be significantly more sensitive than peroxidase-conjugated antibody methods. Commercially this is known as the Vectastain ${ }^{\circledR} \mathrm{ABC}$ labelling procedure. Briefly, sections were incubated in blocking buffer $(0.05 \mathrm{M}$-Tris buffer, $\mathrm{pH} 7.6$, containing $0.1 \% \mathrm{BSA}, 0.1 \%$ gelatin, $0.01 \%$ bovine gamma globulin, and $0.01 \%$ merthiolate) containing avidin at $25 \mu \mathrm{g} / \mathrm{ml}$ to block endogenous tissue biotin. After washing in blocking buffer, sections were incubated in primary antisera as described above (1:500) and biotin $(1 \mu \mathrm{g} / \mathrm{ml})$. After washing, sections were incubated in biotinylated anti-rabbit IgG (1:200; Vector Laboratories), followed by incubation in $0 \cdot 3 \%$ hydrogen peroxide in methanol to suppress endogenous tissue peroxidase. After washing, sections were incubated in avidin-biotinylated peroxidase-complex (ABC, 1:100; Vector Laboratories), followed by incubation in diaminobenzidine to demonstrate the peroxidase activity.

The specificity of the primary antisera for their appropriate mouse immunoglobulin class was confirmed by radial immunodiffusion tests. Each antiserum reacted with its antigen (mouse myeloma IgA (MOPC 315; Litton Bionetics) and chromatographically purified mouse IgC (Cappel 
Laboratories) ) but not with any dilution of the other immunoglobulin. Additional specificity controls were carried out on histological sections: labelling was negligible when non-immune serum was substituted for primary antiserum, labelling was strongly inhibited when an excess of the relevant mouse immunoglobulin was added to primary antiserum, and labelling was undiminished when an excess of the irrelevant mouse immunoglobulin was added to the primary antiserum. Positive controls for each primary antiserum were obtained by labelling IgA and IgG plasma cells in sections of duodenum.

Quantitation of plasma cells. For each hormone treatment or control group 2-5 mice were used. The total number of IgA plasma cells per histological section was counted in about 10 labelled sections from each mouse, a total of 399 sections from 43 mice. IgG plasma cells were likewise counted in 7 treatment groups, with a total of 318 labelled sections being counted from 25 mice. Table 1 gives the average number of plasma cells per histological section in each treatment or control group. Although the data are presented in a single table for comparison, the 2 experiments were done sequentially rather than concurrently.

\section{Results}

The number of plasma cells in the uteri of ovariectomized mice varied with the hormonal regimen used to stimulate the uterine horns. Data from 2 experiments involving 9 hormonal treatments are summarized in Table 1 . There was generally good agreement between Exp. I, in which an antibodyperoxidase conjugate was used for immunoglobulin labelling, and Exp. II, in which the avidinbiotin labelling technique was used. A comparison of the 7 hormone-treated groups by analysis of variance indicated that there were significant differences between the means of the group $(P<0.001)$. Compared to untreated animals, administration of oestradiol alone caused an increase in the number of plasma cells in Exps I and II ( $t$ tests, $P<0.001$ in each case), as did treatment with progesterone alone in Exp. II ( $t$ test, $P<0 \cdot 001$ ). Furthermore, there were more plasma cells in the uterus after treatment with a combination of oestradiol and progesterone than after treatment with oestradiol alone ( $t$ test on pooled data from Exps I and II, $P<0.0005$ ). Clearly, the largest number of plasma cells was observed after treatment with oestradiol followed by progesterone or progesterone + oestradiol. A comparison of these results with the results of treatment with oestradiol alone in Exps I and II showed that the differences were significant $(t$ tests, $P<0.001$ in each case).

Table 1. The effect of ovarian hormones on the number of plasma cells containing IgA and IgG in the uteri of ovariectomized mice

\begin{tabular}{|c|c|c|c|c|c|c|c|c|c|c|}
\hline \multirow[b]{2}{*}{ Exp. } & \multicolumn{8}{|c|}{ Days of treatment } & \multirow{2}{*}{$\begin{array}{c}\text { Mean } \pm \text { s.e.m. } \\
\text { no. of IgA } \\
\text { plasma cells }\end{array}$} & \multirow{2}{*}{$\begin{array}{l}\text { Mean } \pm \text { s.e.m } \\
\text { no. of IgG } \\
\text { plasma cells }\end{array}$} \\
\hline & $1^{*}$ & 2 & 3 & 4 & 5 & 6 & 7 & 8 & & \\
\hline I & $\begin{array}{l}- \\
\bar{E} \\
\mathbf{E}\end{array}$ & $\begin{array}{l}- \\
\bar{E} \\
E\end{array}$ & $\begin{array}{l}- \\
\bar{E} \\
E\end{array}$ & $\begin{array}{l}- \\
- \\
-\end{array}$ & $\begin{array}{l}- \\
- \\
-\end{array}$ & $\begin{array}{l}\bar{E} \\
\mathbf{P} \\
\mathrm{Pe}\end{array}$ & $\begin{array}{l}\bar{E} \\
P \\
P e\end{array}$ & $\begin{array}{c}\text { K } \\
\text { EK } \\
\text { PK } \\
\text { PeK }\end{array}$ & $\begin{array}{l}\cdot 2 \cdot 3 \pm 0 \cdot 5 \\
14 \cdot 0 \pm 1 \cdot 3 \\
31 \cdot 0 \pm 2 \cdot 7 \\
33 \cdot 0 \pm 2 \cdot 8\end{array}$ & $\begin{array}{l}0.6 \pm 0.2 \\
3.8 \pm 0.5 \\
7.6 \pm 1 \cdot 2 \\
5.6 \pm 1 \cdot 0\end{array}$ \\
\hline II & $\begin{array}{l}- \\
\overline{-} \\
\bar{E}\end{array}$ & $\begin{array}{c}- \\
\bar{E} \\
\mathrm{E}\end{array}$ & $\begin{array}{l}- \\
\overline{-} \\
\bar{E}\end{array}$ & $\begin{array}{l}- \\
- \\
-\end{array}$ & $\begin{array}{l}- \\
- \\
-\end{array}$ & $\begin{array}{c}\bar{E} \\
\mathrm{P} \\
\mathrm{EP} \\
\mathrm{P}\end{array}$ & $\begin{array}{c}\bar{E} \\
P \\
E P \\
P\end{array}$ & $\begin{array}{c}\text { K } \\
\text { EK } \\
\text { PK } \\
\text { EPK } \\
\text { PK }\end{array}$ & $\begin{array}{r}0.9 \pm 0.5 \\
13 \cdot 9 \pm 1 \cdot 3 \\
15 \cdot 3 \pm 1 \cdot 0 \\
20 \cdot 0 \pm 1 \cdot 0 \\
29 \cdot 2 \pm 3 \cdot 1\end{array}$ & $\begin{array}{c}0 \\
1 \cdot 0 \pm 0 \cdot 3 \\
0 \cdot 7 \pm 0 \cdot 2 \\
- \\
-\end{array}$ \\
\hline
\end{tabular}

* Day 1 is about 3-4 weeks after ovariectomy.

$\mathrm{K}$, killed on Day 8 of treatment $4-7 \mathrm{~h}$ after the last hormone injection; E, $0.1 \mu \mathrm{g}$ oestradiol-17ß; $\mathrm{P}, 1 \mathrm{mg}$ progesterone; e, $0.01 \mu \mathrm{g}$ oestradiol $-17 \beta$. 


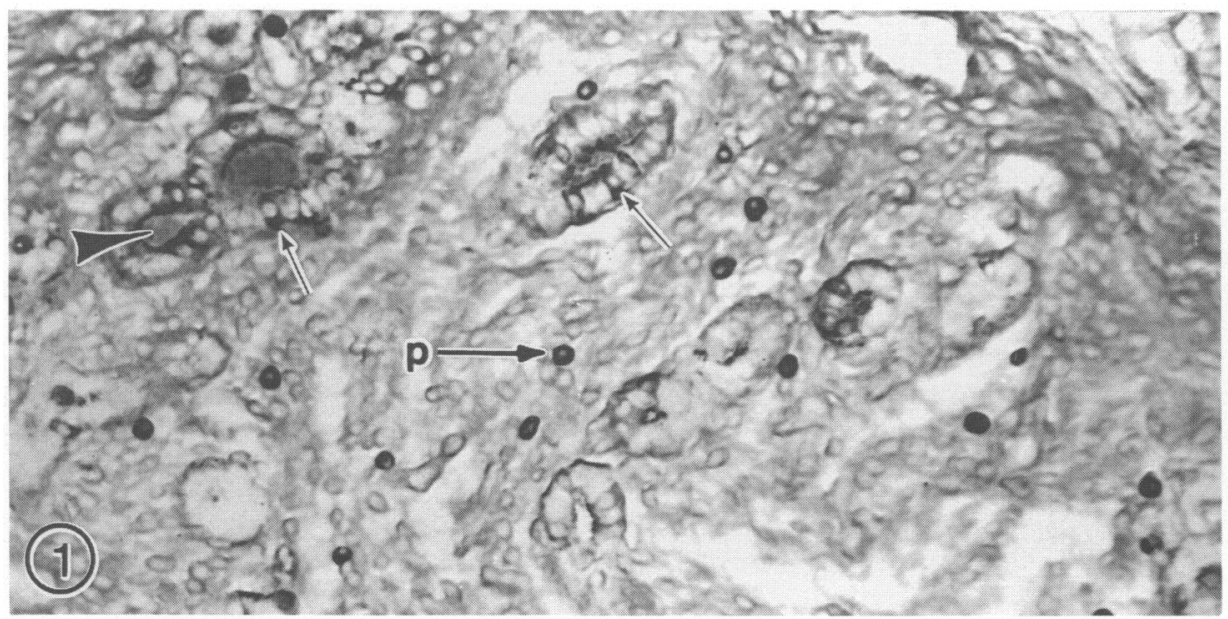

Fig. 1. Light micrograph of a section through the endometrium of an ovariectomized mouse treated with a combination of oestradiol and progesterone for 3 consecutive days (Exp. II). The section was labelled to detect IgA using the ABC technique. Peroxidase reaction product is present in plasma cells (P), some glandular epithelial cells (arrows), and glandular lumina (arrowhead). $\times 210$.

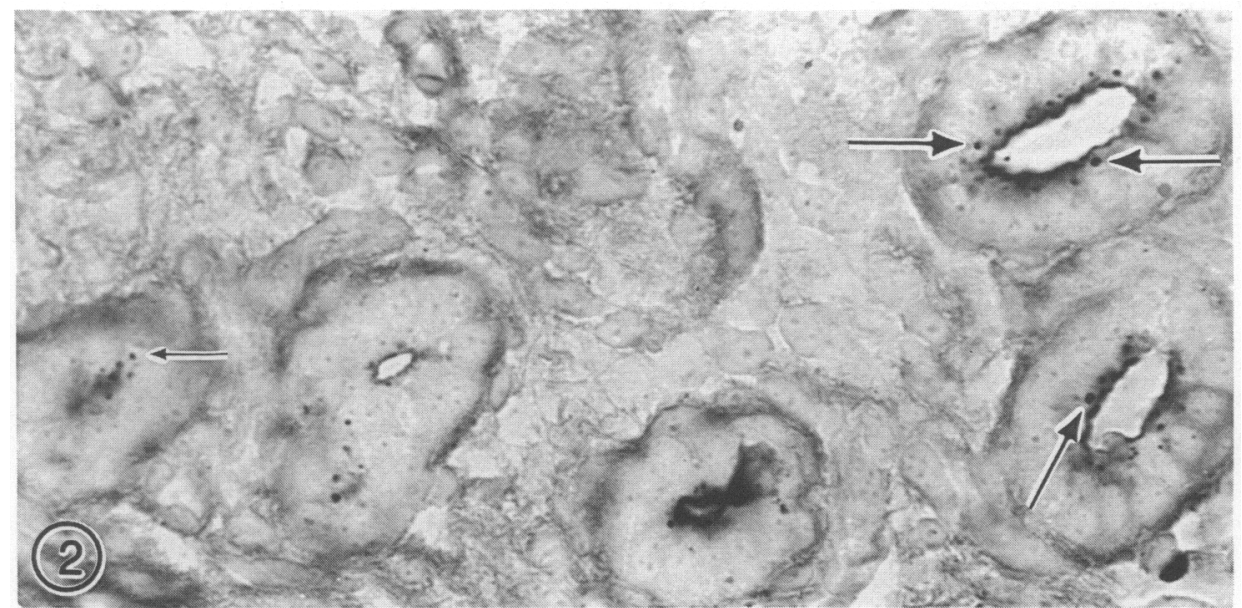

Fig. 2. Light micrograph of a section through the endometrium of an ovariectomized mouse treated with a combination of oestradiol and progesterone for 3 consecutive days (Exp. II). The section was labelled to detect $\operatorname{IgA}$ using the $\mathrm{ABC}$ technique, and shows peroxidase reaction product in small granules at the apical end of numerous glandular epithelial cells. $\times 600$.

The number of IgG plasma cells in the endometrium was relatively small compared to the number of IgA cells in all treatment groups. In many sections the dark staining of IgG in the endometrial interstitial spaces made it difficult to distinguish labelled IgG plasma cells. In those instances when IgG cells were counted, their numbers showed the same trend as the IgA cells but were too small to allow statistical analysis or firm conclusions (Table 1). 


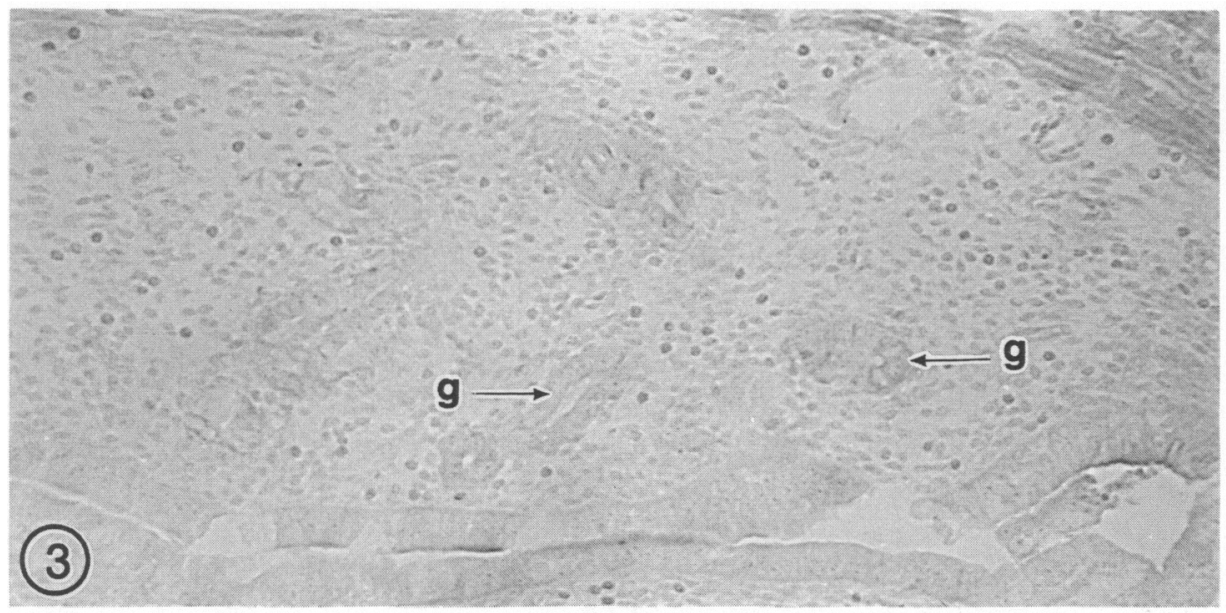

Fig. 3. Light micrograph of a section through the endometrium of an ovariectomized mouse treated with oestradiol for 3 consecutive days. The section was labelled to detect IgA using the $\mathrm{ABC}$ technique, but non-immune serum was substituted for the primary antiserum. The section is unstained. $\mathrm{g}$, gland. $\times 90$.

Plasma cells containing $\operatorname{Ig} \mathrm{A}$ were located mainly around the endometrial glands. There was diffuse labelling of IgA in some gland lumina of all hormone-treated mice but the amount was variable (Fig. 1). In mice treated with oestradiol and progesterone combined or oestradiol followed by progesterone, but not with oestradiol or progesterone alone, IgA was detected as diffuse staining throughout occasional cells (Fig. 1), or as small granules in the apical part of some gland epithelia (Fig. 2). The granules were seen only in uteri labelled with the avidin-biotin technique and not with the antibody-peroxidase conjugate. There was no staining of IgA in the luminal epithelial cells with either method and little, if any, labelling in the interstitial spaces of the endometrial stroma. There was some IgG staining in gland lumina of mice treated with progesterone alone or oestradiol followed by progesterone, but there was no labelling of IgG in glandular or luminal epithelial cells with either labelling method. IgG was present in the stroma in variable amounts. A control section is shown in Fig. 3.

\section{Discussion}

The results presented here demonstrate the influence of ovarian hormones on the number of plasma cells in the uteri of ovariectomized mice. Treatment for 3 days with oestradiol caused a large increase in the number of endometrial plasma cells, and progesterone was equally effective. Treatment with a combination of oestradiol and progesterone resulted in the same or a slightly larger number of plasma cells than with oestradiol or progesterone alone. When progesterone followed oestradiol in a hormonal sequence that prepares the endometrium for embryo implantation (Finn \& Martin, 1969), the number of plasma cells increased to more than twice the number present after oestradiol alone. These results are consistent with observations on plasma cell numbers in intact mice during normal pregnancy. Bernard et al. (1981) reported that the number of plasma cells containing IgA in mouse uteri during early pregnancy was larger than at pro-oestrus. Similarly, 
on Days 4 and 5 of pregnancy, which corresponds to the sequential oestradiol-followed-byprogesterone treatment used above, the number of IgA- and IgG-containing plasma cells in the mouse uterus was more than twice the number present at oestrus or Day 1 of pregnancy, when the uterus is stimulated mainly by oestradiol (Parr \& Parr, 1985a). Also, from Day 11 of pregnancy to term, when the uterus is stimulated by a high concentration of progesterone (McCormack \& Greenwald, 1974), the number of plasma cells of both isotypes in the uterus was large (Parr \& Parr, $1985 \mathrm{~b}$ ). The present data indicate that the increased number of endometrial plasma cells present at the time of implantation compared to oestrus is due, at least in part, to the action of progesterone on an oestrogen-primed uterus. Factors in addition to progesterone may also be involved, such as bacteria in the uterus after mating (Parr \& Parr, 1985c) or the presence of spermatozoa or the blastocyst in the uterine lumen.

Contrary to the present report, other investigators studying the effects of ovarian hormones on ovariectomized animals have reported that, while oestradiol stimulated an increase in uterine plasma cell numbers, progesterone alone and a combination of oestradiol and progesterone failed to do so in rats (Wira et al., 1980), and did so rather weakly in mice (Canning \& Billington, 1983). Based on these observations, it has been suggested that progesterone antagonizes an oestrogenstimulated increase of plasma cells in the uterus (Wira et al., 1980). This suggestion appears to conflict with the observations of intact mice mentioned above, which demonstrated relatively large numbers of plasma cells in the endometrium during progesterone dominated periods. However, progesterone is not presented this way in intact rats and mice; progesterone always acts upon a genital tract that has been previously primed by oestradiol. Consequently, the most relevant data obtained from the ovariectomized animals are that oestradiol stimulated a large increase in the number of plasma cells in the uterus and that progesterone or progesterone + oestradiol after oestradiol caused a substantial further increase, as shown in the present study. These observations are consistent with the available information from studies of intact animals, including humans (Schumacher, 1973; Murdoch, Buckley \& Fox, 1982).

Little information is available concerning immunoglobulin transport into the uterine lumen. In ovariectomized mice treated with a combination of oestradiol and progesterone or oestradiol followed by progesterone, we observed $\operatorname{IgA}$ in plasma cells in the endometrium surrounding glands, in some gland epithelial cells, and in some gland lumina. This suggests that there is, under these conditions, a local secretion of IgA into the uterine lumen across the glandular epithelium. This is consistent with previous observations in mice during the oestrous cycle (Rachman et al., 1983) and pregnancy (Bernard et al., 1981; Parr \& Parr, 1985a). Immunoglobulin or secretory component have also been detected in the cytoplasm of uterine luminal or glandular epithelial cells in mares (Kenney \& Khaleel, 1975), rats (Wira, Sullivan \& Sandoe, 1983), sows (Hussein, Newby \& Bourne, 1983), rabbits (Symons \& Herbert, 1971), and humans (Kelly \& Fox, 1979; Suzuki, Ogawa, Tamada, Nagura \& Watanabe, 1984). In the present studies, immunoglobulin $G$ was also detected in the lumina of a few glands, again suggesting some transport into the uterine lumen across glandular epithelium. Most of the IgG was probably systemic in origin because the number of IgG plasma cells in the endometrium was small compared to the number of IgA cells. Immunoglobulin $\mathrm{G}$ was not detectable in luminal epithelium. However, it is well documented that immunoglobulin labelling in epithelial cells is markedly dependent on tissue fixation and other variables (Brandtzaeg, 1982). Hence, the failure to detect IgG in luminal and glandular epithelial cells and IgA in luminal epithelium does not imply that the immunoglobulins were not present in the cells. More information is needed about the pathway of immunoglobulin transport into the uterine lumen, about possible differences between luminal and glandular epithelial cells in this process, and about the endocrine regulation of such transport.

We thank Kimberly Munaretto, Jayne Precup, Scott Berry and Bruce Jones for excellent technical assistance and Candida Trueblood for typing the manuscript. This work was supported by NIH research grant HD 17337. 


\section{References}

Bernard, O., Rachman, F. \& Bennett, D. (1981) Immunoglobulins in the mouse uterus before implantation. $J$. Reprod. Fert. 63, 237-240.

Brandtzaeg, P. (1982) Tissue preparation methods for immunocytochemistry. In Techniques in Immunocytochemistry, Vol. 1, pp. 1-76. Eds G. R. Bullock \& P. Petrusz. Academic Press, New York.

Canning, M.B. \& Billington, W.D. (1983) Hormonal regulation of immunoglobulin and plasma cells in the mouse uterus. J. Endocr. 97, 419-424.

Finn, C.A. \& Martin, L. (1969) Hormone secretion during early pregnancy in the mouse. $J$. Endocr. 45, $57-65$.

Hussein, A.M., Newby, T.J. \& Bourne, F.J. (1983) Immunohistochemical studies of the local immune system in the reproductive tract of the sow. J. Reprod. Immunol. 5, 1-15.

Kelly, J.K. \& Fox, H. (1979) The local immunological defence system of the human endometrium. $J$. Reprod. Immunol. 1, 39-45.

Kenney, R.M. \& Khaleel, S.A. (1975) Bacteriostatic activity of the mare uterus: A progress report on immunoglobulins. J. Reprod. Fert., Suppl. 23, 357-358.

Mazurkiewicz, J.E. \& Nakane, P.K. (1972) Light and electron microscopic localization of antigens in tissues embedded in polyethylene glycol with a peroxidase-labeled antibody method. $J$. Histochem. Cytochem. 20, 969-974.

McCormack, J.T. \& Greenwald, G.S. (1974) Progesterone and oestradiol-17 $\beta$ concentrations in the peripheral plasma during pregnancy in the mouse. $J$. Endocr. 62, 101-107.

Murdoch, A.J.M., Buckley, C.H. \& Fox, H. (1982) Hormonal control of the secretory immune system of the human uterine cervix. J. Reprod. Immunol. 4, 23-30.

Parr, M.B. \& Parr, E.L. (1985a) Immunohistochemical localization of immunoglobulins $A, G$ and $M$ in the mouse female genital tract. J. Reprod. Fert. 74, $361-370$.
Parr, E.L. \& Parr, M.B. (1985b) Localization of immunoglobulins in the mouse uterus, embryo, and placenta during the second half of pregnancy. $J$. Reprod. Immunol. (in press).

Parr, E.L. \& Parr, M.B. (1985c) Secretory immunoglobulin binding to bacteria in the mouse uterus after mating. J. Reprod. Immunol. 8, 71-82.

Rachman, F., Casimiri, V., Psychoyos, A. \& Bernard, O. (1983) Immunoglobulins in the mouse uterus during the oestrous cycle. J. Reprod. Fert. 69, 17-21.

Rachman, F., Casimiri, V. \& Bernard, O. (1984) Maternal immunoglobulins $\mathrm{G}, \mathrm{A} \& \mathrm{M}$ in the mouse uterus and embryo during the postimplantation period. $J$. Reprod. Immunol. 6, 39-47.

Schumacher, G.F.B. (1973) Soluble proteins in cervical mucus. In The Biology of the Cervix, pp. 201-233. Eds R. J. Blandau \& K. S. Moghissi. University of Chicago Press, Chicago.

Suzuki, M., Ogawa, M., Tamada, T., Nagura, H. \& Watanabe, K. (1984) Immunohistochemical localization of secretory component and $\operatorname{IgA}$ in the human endometrium in relation to menstrual cycle. Acta histochem. cytochem. 17, 223-229.

Symons, D.B.A. \& Herbert, J. (1971) Evidence of immunoglobulins in fluids of the rabbit genital tracts and the distribution of IgG-globulin in the tissues of the female tract. $J$. Reprod. Fert. 24, 55-62.

Wira, C.R., Hyde, E., Sandoe, C.P., Sullivan, D. \& Spencer, S. (1980) Cellular aspects of rat uterine IgA response to oestradiol and progesterone. J. Steroid Biochem. 12, 451-459.

Wira, C.R., Sullivan, D.A. \& Sandoe, C.P. (1983) Epithelial cell involvement in the estradiol-stimulated accumulation of $\operatorname{IgA}$ in the rat uterus. J. Steroid Biochem. 19, 469-474.

Wolosewick, J.J. \& DeMey, J. (1982) In situ demonstration of tubulin and actin-containing structures in glutaraldehyde-fixed PEG-embedded tissue sections. Anat. Rec. 202, 207A, Abstr.

Received 18 July 1985 